\title{
The Development of Android Based Digital Module Materials for Human Nerve Systems in SMA Negeri 1 Cengal, Ogan Komering District Ilir
}

\author{
Salman Alfaris ${ }^{1 *}$, Bukman Lian², Mulyadi $^{2}$ \\ ${ }^{1}$ SMP Negeri 8 Tulung Selapan,
${ }^{2}$ Universitas PGRI Palembang
${ }^{*}$ Corresponding author. E-mail: ${ }^{1}$ kuroko.2390@gmail.com
}

\begin{abstract}
This study aims to develop-based digital module on android a feasible and effective the nervous system material in humans. The development model used in this research is ADDIE. The research subjects were three experts and one educational practitioner consisting of Information Technology System (IT) experts, media experts, and biology learning practitioners, and then field trials were conducted twice. The results of the validation given by material experts got an average score of 4.6, the average score given by media experts was 4.7 , the average score given by IT experts was 4.0, and education practitioners gave an average score. an average of 4.7, from all experts the average score given for the development of digital modules based on Android is 4.5 with a percentage of $90.0 \%$ in the "categoryvery feasible". Before and after the lesson was given a test, then analyzed. The results of the paired t-teston the pretest and posttest scores obtained a significant value of 0.000 because the significant value is smaller than 0.025 , Hence, there is a significant difference in the ability of students before and after using the-based digital module android. So it can be concluded that the-based digital module android of nervous system material in humans developed with the ADDIE model is declared feasible and effective to use.
\end{abstract}

Keywords: Development Digital Modules, The Nerve System in Humans, Android

\section{INTRODUCTION}

The school is a formal educational institution that provides the knowledge and skills to equip learners to prepare skilled human [1]. The teacher is an important factor in shaping the skills of students. The teacher's efforts to shape the skills of students and the challenges of globalization today must be answered by educators by using innovative information technology media in learning [10][11].

The learning module, especially in biology subjects, aims to enable students to master certain concepts in biology material and their relation to realistic conditions in the environment. Mastering implies that learning biology must make students not only know (knowing) and memorizing (memorizing) about biological concepts, but also make students understand and know the concepts and relate a concept to other concepts and in conditions that are real [2]. Good learning is learning that involves students actively not only centering on the teacher, this is still not implemented according to the 2013 Curriculum seen in classroom observations during the biology learning process.
The results of observations made in facility schools are very adequate for the maximum learning process. This is evidenced by the presence of Internet signals throughout the school environment, allowing students to bring laptops and smartphones. so that the existence of these facilities should be used as a driving force in the educational process.

Entering the industrial revolution era 4.0 marked by robots, machine learning, blockchain, artificial intelligence, internet of things (IoT), driverless vehicles, biotechnology, demands that the world of education adapt quickly to the learning process. One of them is the use of machine learning (learning tools) to be applied in the learning process. The use of machine learning can be in the form of a digital module that is easy to operate and does not impose a burden on its use. One of them is the use of smartphones to be used as learning media.

Currently students must be equipped with the ability to access, analyze, and synthesize information, and the learning process has begun to change where students have different demands. Students are required to have 10 skills including critical thinking skills, leadership, communication, collaboration, adaptability, innovation, productivity and accountability, the ability and spirit of 
entrepreneurship, global citizenship [3]. According to the Delors Report, the four pillars of education are learning to know, learning to do, learning to be, and learning to live together. In his statement, learning to do includes information, media, and technology literacy. So that the use of gadgets and digital literacy is indispensable for the learning process in the 21st century [4].

In addition, the characteristics of millennial era students (children born in 2000 and over or generation Z) who want everything that is practical. Millennial generation has characteristics that like freedom, rely on instant information speed, like to personalize, like to study or work in an innovative environment, hyper technology and actively collaborate [5]. From the above opinion, today's students no longer use books as a source of information, but they use their smartphones to get information. Even though according to Afifah (2015), smartphones have a lot of negative impacts, especially on students. This can be seen from the decrease in grades both cognitive and psychomotor. One reason is that students experience gadget addiction. At the time of conducting the initial survey it was known that students always used their smartphones during breaks. This is also done when returning from school from the survey results that every time students come home to operate their smartphones for five to fifteen minutes before they leave the classroom. Meanwhile, from the results of the interview, it was known that if students were not at home, they always operated smartphones for social media activities and online games. In the results of the interview, it was also known that the device they used was an Android smartphone, this was because the price of an Android smartphone was more affordable than the IOS (Apple iPhone).

\section{METHOD}

This research is a product development research in the form of an android-based digital module. The reason for the creation of a digital module for high school biology subjects with the material on the nervous system in humans has complex and abstract characteristics that many students find difficult.

The results of development research are not only the development of an existing product but also to find knowledge or answers to practical problems [7]. The design and development method is also defined as a research method used to produce certain products and test the effectiveness of these products. Development research must have three important parts including development models, development procedures, and product trials [8].

Development of an-based digital module Android using the ADDIE model which begins with a needs analysis to determine constraints in learning, designing the initial module design (draft material), developing based digital module Android, implementing digital modules, and evaluating the results of using digital learning modules the.

The data collection technique uses a validation sheet and then the quantitative value will be converted into a qualitative value. The data analysis technique in research is to calculate the percentage of the validation value and for the effectiveness of the digital module by using the paired sample t-test.

\section{RESULTS}

\subsection{The results of the development module}

The result of based digital module Android are an adaptation of the ADDIE development research steps, namely the stages such as 1) analysis, 2) design, 3) development, 4) implementation, 5) evaluation. The description of these steps is as follows.

\subsubsection{Analysis Phase}

In the analysis stage the researcher conducted interviews with the biology teacher at SMA Negeri 1 Cengal. From the results of interviews with the teacher regarding class XI material which was felt to be difficult for students to understand, the teacher thought that students did not understand if learning material on the nervous system in humans was only taught by conventional methods and from books in schools, so that learning was less conducive and learning outcomes were average. the average is still below the KKM.

\subsubsection{The Design Phase (Design)}

Development of an Android-based Digital Module was inspired by the many students who use Android devices as gadgets. During learning, students are allowed to access the internet with smartphones to find assignments and learning resources. Then further the arrangement of the nervous system material in humans is obtained from various reference sources. The material that has been collected is included in the sub material to make it easier for students to learn. The software used in development is MIT AppInventor. This software was developed by the Massachusetts Institute of Technology from the United States. The choice of the software was due to a programming language that was simple and easy to use.

\subsubsection{The Development Android-Based Digital Module}

Based on the designed design and the programming language that has collected to be one planning, then all put together to produce an Android application that has a memory size of $8.8 \mathrm{Mb}$ (Mega Byte). After the digital module has been developed, expert validation is carried out to determine the feasibility of the digital material and module and also to obtain input so that the resulting 
media is better. The results obtained from the expert's assessment are as follows:

\subsubsection{The Validationof Expert Material}

The validation expert material was conducted by Dr. Syaiful Eddy, M.Si, to assess the material in the development of an-based digital module Android by collecting input and suggestions through a questionnaire. The results of the questionnaire obtained can be seen in graph 1 , as follows:

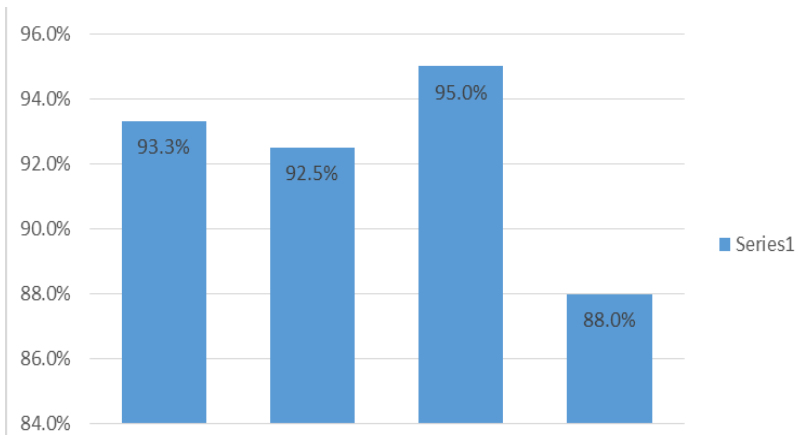

Graph 1 The Validation of Expert Material

Based on the data in graph 1 above, it can be seen from the feasibility of the curriculum aspect with an average score of 4.7 with a percentage of assessment of aspects of the digital module curriculum 93.3\%, the aspect of presenting the material with an average score of 4.6 with a percentage of $92.5 \%$. evaluation aspects with an average score of 4.8 with a percentage of $95.0 \%$, and linguistic aspects with an average score of 4.4 with a percentage of $88.0 \%$. Of the four categories, an average of 4.6 and a percentage of $92.0 \%$. So that it is in the range> $80-100 \%$ with the "categoryVery Appropriate".

Apart from being given an assessment, the material expert also provides information on errors that must be corrected. Types of errors in the absence of citation for each paragraph, and the material is sorted by subsection.

Furthermore, these types of errors are used as the basis for the revision stage to improve the products being developed.

\subsubsection{The Assessment of Media Expert}

The assessment of media expert was carried out by Dr. Happy Fitria, M.Pd, on the digital module to assess the feasibility of an-based digital module Android with the following results:2.Media

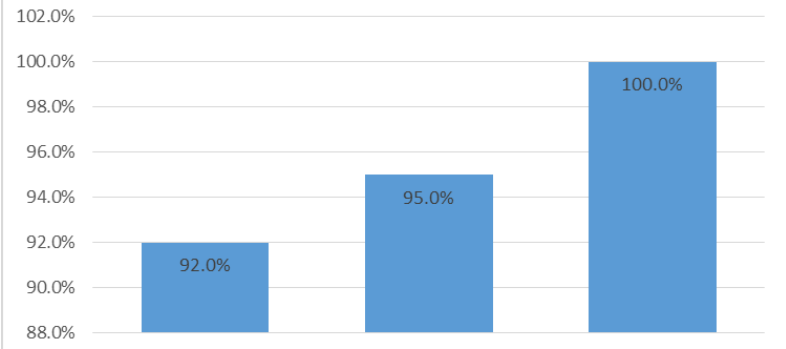

Graph 2 The Assessment of Media Expert

Based on the data above, it can be seen from the three categories that an average of 4.7 and a percentage of 94 was obtained. \%. So that it is in the range> 80$100 \%$ with thecategory "Very Appropriate". Media experts also provide error information that must be corrected, namely: Application developer information is not used as a splash screen, YouTube videos can be played, the background is replaced with a degraded background to make it attractive. Then from the input, the digital module is repaired.

\subsubsection{The Assessment of Expert Information Technology (IT)}

Information Technology System Expert Validation conducted by Mr. AsnurulIsroqmi, SI,. M.Kom. With the following results:

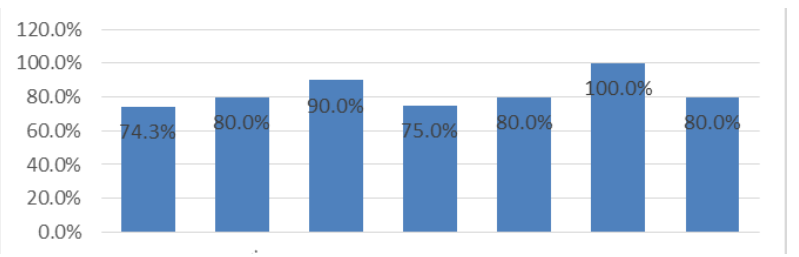

Graph 3. The Evaluation Assessment of Expert IT

Based on the data in graph 3, it can be seen that overall of the seven categories obtained an average of 4 and a percentage of $80 \%$. So that it is in the range> 70$80 \%$ with thecategory" Eligible".

With suggestions for improvement, namely certain content links are not yet accessible.

\subsubsection{Practitioner Evaluation Assessment of Practitioner}

Validation of learning conducted by Mrs. UmiKalsum, S.Km. (Biology teacher at SMA Negeri 1 Cengal) the results given are as follows: 


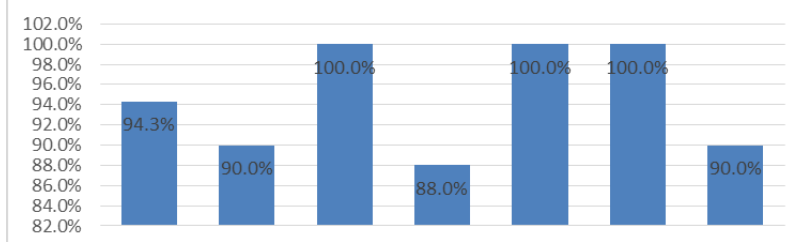

Graph 4. The Assessment of Educational Practitioners

Graph 4 illustrates that overall the seven categories obtained an average of 4.7 and a percentage of $93.3 \%$ so that it is in the range> $80-100 \%$ with thecategory "Very Eligible". Then the suggestions given for improvement are on the background of the question, which makes the questions illegible.

Overall, education experts and practitioners have the average value given by the digital module score of 4.5 and the average percentage of $90.0 \%$. This value is in the range> $80-100 \%$ with the category "VeryAppropriate" can be seen in graph 5. However, there are a number of things that need to be improved, after correcting according to the expert's advice, the digital module can be implemented to obtain user responses.

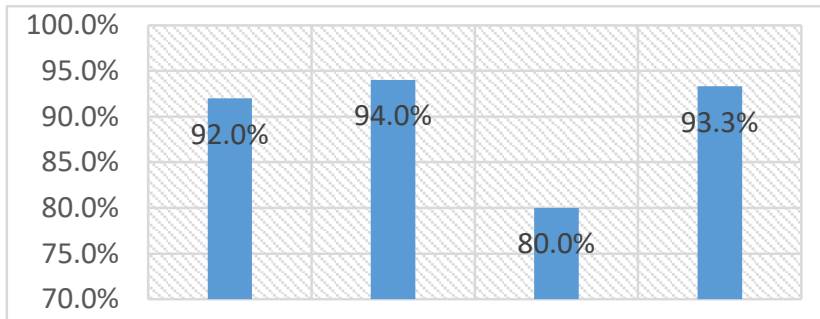

Graph 5. The Assessment of Educational Experts and Practitioners of Android-Based Digital Modules.

\subsubsection{The Phase Implementation}

The phasestage is carried out in two stages, namely small group trials and large group trials. Small group trials wasto find out whether the digital module can be used properly. The results of the interview about the developed media show that the digital module is easy to use and can be operated independently. While the results of the large group trial were the results of the pretest and posttest were carried out by Paired Samples $t$-test :Sig. (2-tailed $=0.000<0.025$. Android-based digital module material on the nervous system in humans is declared effective so that it is suitable for use in Biology learning. Then after completing the learning process, a module assessment is carried out with a questionnaire and the results of the Student Assessment of the Android-based digital module 89 are obtained. $8 \%$ with the category "very worthy"

\section{Appropriate 3.1.5 Evaluation}

The evaluation stage is carried out to see the extent to which the digital module has been successfully developed by looking at all the data obtained from the development and implementation stages. So that the conclusion is that the Android-based digital module is the nervous system material in humans it is suitable to be used as a digital module, but there are some that must be improved to make it better

\section{DISSCUSSION}

Based on the results of the development research using ADDIE models described that based digital module Android-nervous system material in humans is feasible and effective to use. This is in line with DwiMasfufah's research entitled Development of Android-Based Mobile Learning (M-Learning) Learning Media on Virus Material for Class X SMA Students, the results show thatmedia is m-learning androidbasedsuitable for use with biology learning for class X SMA / MA students. [9]. Another finding was also conducted by Handoko who conducted research on the Learning Appypie Android mobile media showing that the Learning Appypie Android media is valid, practical and effective [10].

In addition, the result from the pre-test and post-test scores described that there is a significant increase in the average value of 14.69. Then the results of the paired ttest analysis obtained a significant value of 0.000 . Because the significant value is less than 0.025 , hence there is a significant difference in the ability of students before and after using an android-based digital module for nervous system material in humans at SMA Negeri 1 Cengal, so the digital module based on android material for nervous system in humans is declared effective so that it is suitable for use in learning Biology.

The results of this research are in line with the opinions of Husmita, Verawati, and Anggraeni regarding the development of modules that are suitable for use and effectively used by students during field trials and are able to assist students in learning and understanding the material being taught.

However, in this development there are several limitations in the development of digital modules based on Android Nervous System Material in Humans as follows: 1) Smartphones with low specifications cannot use this media; 2) Videos cannot be taken offline due to memory limitations; 3) Not everyone can develop this media because of limited knowledge of programming languages; 4) Development requires expensive equipment; 5) The application can only be used in the Android Operation System, so Apple cannot use it for iOS. Advantages of Android-Based Digital Modules Android-based digital modules have several advantages which include: 1) Easy to use; 2) this media Has a small memory of $8.85 \mathrm{Mb}$; 3) Easy to understand; 4)Easy to redevelop; 5)Can be operated with entry level mobile phones; 6) Easy to share. In 
addition, there are shortcomings of Android-based digital modules, which include: 1) Cannotbe used for old cellphones; 2) Minimum Android that can run is Android 7.0; 3) The junk memory from video playback is not deleted automatically.

\section{CONCLUSION}

Based on the results of the development and discussion, there are several things that can be concluded from this study, namely as follows. The process of making the first media started from analyzing the problems found in SMA Negeri 1 Cengal. The second stage is the creation of a programming language. The third stage is to combine programming languages and materials using the software MITAppInventor2. Next is the judgment by the expert judgman. The fourth stage is implementation, which is carried out twice, namely small trials and large group trials. The last stage is the evaluation stage. The developed digital module is considered very suitable for use as a digital module of the nervous system material in humans. This is reviewed based on the results of the expert judgment.

\section{REFERENCES}

[1] Rahmayanti. (2015). Use of IT Media in Learning. Accessed from http://download.portalgaruda.org/article.title=Medi aITDalamPembelajaran Accessed on March 4, 2020 at $13: 32$ WIB.97 p.

[2] Salim, Abdi. (2016). Relationship of Responsibility with Student Learning Outcomes in Biology Learning in Class XI.Science at SMAN 2 LintauBuo.Undergraduate thesis at IAIN Batusangkar.Batusangkar.

[3] Barry, Cushway. (2012). Human Resource Management. Jakarta: PT. Elex Media

[4] Delors.J. (2014). Learning: The treasure within. Report to UNESCO of the international Commission on Education for the Twenty-first Century: Printed by Presses Universitaires de France, Vendome.

[5] Tapscott, Don. (2008). Grown Up Digital How The Net Generation Is The World. New York: McGraw Hill

[6] Sugiyono. (2011). Qualitative and Quantitative Research Methods $R \& D$. Alfabeta: Bandung

[7] Puslitjaknov Team. (2008). Development Research Methods.BalitbangDiknas. Jakarta.

[8] Masfufah, Dwi. (2015). Development of AndroidBased Mobile Learning (MLearning) Learning Media on Virus Material for Class X SMA / MA Students. Yogyakarta: UIN SunanKalijaga. Http://digilib.uinsuka.ac.id/view/creators/
DWI_MASFUFAH $=$ 3ANIM $=$ 2E_11680055 = $3 \mathrm{~A}=3 \mathrm{~A} \cdot \mathrm{html}$

[9] Handoko, A. (2018). Development of android appypie mobile learning media.raden intan state islamic university, http://repository.radenintan.ac.id/4789/1/ARDI\%20 HANDOKO.pdf.

[10] Wawan, W., Marsigit, M., Ningsih, E. F., Widyawati, S., Kusumaningtyas, W., Mahmudi, M., ... \& Setiawan, A. (2018). TechnologyIntegrated Collaborative Learning: Convenient Alternative in Developing the Problem Solving Capability and Positive Attitude. International journal of engineering \& technology, 7(3.2), 737740.

[11] Halawa, M. V. B. (2021). Efektivitas Pemanfaatan Platform Media Sosial dalam Pembelajaran Praktikum Secara Daring. Attractive: Innovative Education Journal, 3(1), 52-64. 